\title{
FEATURE CAREER STRUCTURE OF THE IMAGE AT DIFFERENT STAGES OF PROFESSIONAL DEVELOPMENT
}

\author{
Dr. Pankratova Irina Anatolievna, Southern Federal University, Rostov-on-Don, Russia \\ E-mail: ckags student@mail.ru \\ Dr. Rogova Evgene Evgenievna, Southern Federal University, Rostov-on-Don, Russia \\ E-mail: evgrogova@yandex.ru
}

\section{A R T I C LE INF O \\ Original Article \\ Received: November, 20.2016. \\ Revised: December, 08.2016. \\ Accepted: December, 12.2016. \\ doi:10.5937/IJCRSEE1602031A \\ UDK \\ 005.96 \\ 37.013 .83}

\section{Keywords:}

career,

career image,

career trajectory,

evaluation

\begin{abstract}
A B S T R A C T
The paper describes research carried out in the framework of the study of representations of professional identity. The aim of this paper is to study the image of the career structure and its structural elements. The study was conducted on a sample of 635 people, among them - 388 women and girls and 247 boys and men. The empirical study was carried out on the basis of faculty «State and municipal management» (students of 1 and 5 courses) and «training of civil servants», Russian. Career image includes three components: structural; informative and emotional evaluation. The content of the career image components changes depending on what stage of professional development the personality is. The structural component in the process of professional development varies from amorphous and illstructured at the first stage of professional development to a clear and specific at the last stage of professional development. The career trajectory changes as follows: at the first, third and fourth stages of professional development the most characteristic is the graph of a career «vertical», and at the second stage it is «plateau». As to the content of career image we can note that the most common for all stages of career development is the dominance of financial goals. Emotional-evaluative component of the career image is maximally differentiated at the second stage of professional development, at all other stages the career image has a common neutral color.
\end{abstract}

(C) 2016 IJCRSEE. All rights reserved.

\section{INTRODUCTION}

In modern Russia, there is a transformation of all spheres of society, the economic crises of recent years and the economic and social restructuring caused a change towards many processes and phenomena, which until now remained outside the purview of psychologists. What used to be considered a deviation from the norm, a product of capitalism, is now considered an important and integral component in a person's life.

More attention has been paid to such concepts as «self-development», «self-educa-

Corresponding Author

Dr. Pankratova Irina Anatolievna, Southern Federal

University, Rostov-on-Don, Russia

E-mail: ckags_student@mail.ru

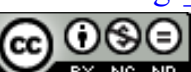

This work is licensed under a Creative Commons Attribution - NonCommercial - NoDerivs 4.0. The article is published with Open Access at www.ijcrsee.com tion», «personal success,» «success in business and professional activities», «career». In many approaches, schools and branches of psychology we can find descriptions of phenomena that serve as the regulator of the individual's actions, perception and comprehension of reality and himself by the person, self-determination in society, building of their personality, way of life, including professional development and career advancement. In contemporary Russian society the aims of education and, consequently, the criteria of its effectiveness have been changed. The main aim of education became the development of personality and realization of its unique human capabilities (Handzic M. 2016; Noe R., Noe A., Bachuber J., 1990). The criterion for evaluating the effectiveness of education is the success of professional activity.

In connection with it the phenomenon of career has become the object of study in many foreign and domestic studies. Foreign research investigates mainly the factors in- 
fluencing the choice and career development, motivation and successful realization (Noe R., Noe A., Bachuber J., 1990; Pankratova I. A., Anikina O. V., 2015).

In Russian psychology the researches in the field of professional career concern mainly the peculiarities of professionals, the content and the dynamics of career, relationships of career success, professional training, development of professional self-consciousness (Rogova E. E., Pankratova I.A., 2012; Pankratova I. A., Anikina O. V., 2015; Rogov E. I., 2014; Sheveleva A. M., Ivanova A. I., 2013; Klimov E. A., 1996).

Thus the idea of own career is a form of professional future management, at the same time ideas about the future planned professional and career way were studied relatively little. Professional development and career advancement of the personality can be managed by the society, and by the man himself, from the inside, through the system of psychic phenomena that serve as the regulator of the behavior and actions of the personality. Such phenomena is "the image of the career".

Although the researchers agree that the image of a career is not static and changes during the acquisition of the new experience, however, there is still no special psychological researches focused on the experimental study of the specific peculiarities of the image of career. The actuality of this study is determined by the consideration of the regularities of the specific way of career on the basis of synthesis of theoretical and experimental works of Russian and foreign researchers.

The image of a career is a way of regulation of life and professional activity of the personality through goal setting, motive formation, sense formation, stimulation and mobilization. The image of the career performs the functions of emotional reinforcement and planning career development.

Despite the undoubted actuality of the study of the career image there is no definite view on the structure and content of this phenomenon in psychological science. The aim of our work is to study the structure of the image of the career (for example, government officials), and to study peculiarities of changes in the content of the image at different stages of career growth of the personality.

\section{THE CONTENT OF CAREER IMAGE STRUCTURE}

\subsection{The career image as psychological phenomenon}

The term "career image" and related concepts are studied extensively in the last ten years. With this term such definitions as "professional component of the image of the world", "career planning", "the ideals of a professional career", "the dynamics of ideas about the professional career", "the image career way" are related.

In the basis of the study of the formation of ideas about their own career is the research of E. A. Klimov about professional component of the image of the world. E. A. Klimov says that the internal (implicit) models, images of "the connected world whole", real holistic world, essentially and not accidentally differ in connection with the types of professions distinguished, for example, by the characteristics of the subject system, which the man deals with as a subject of activity. The idea about professional relativity of an image of the world is a particular expression of the idea of group and individual relativity of displaying objective and subjective reality by different people (Hanina I. B., 1990).

In the works of E. A. Klimov it is said that a person belonging to a particular profession has his own image of the world and world perception. Thus, the activity performed by the person influences the ideas about his future.

I. B. Hanina, focusing on the formation of the subjective model of the world, suggests that among the professionals this formation occurs in the interaction with a specific object of labour and depends on the method of participation in distributed work; type of labour communication; orientation of educational influence during learning of profession (Sheveleva A. M., 2013).

The professional component of the image of the world is formed in the process of teaching and training. The professional component of the image of the world is the system of relations of man to the objective reality through the prism of his profession as complex manifestation and at the same time reflection regulator gained in the process of life.

Analyzing the problem of ideas about their own career of students of psychology A. M. Sheveleva came to its learning through the 
prism of the emotional aspect of the term of career ideals. She gives the following definition to career ideal - it is ideas of the subject about the best desirable career for him which reveals in the following content: professional activity, professional position, realization of vocation, lifestyle, enrichment of experience, professional way or achievements and social recognition (Kirt, N. L., 2000).

In the works of N. L. Kirt the dynamics of ideas about the professional career of the educational psychologists in the process of professional self-determination was analyzed. There were studied the ideas about profession on the basis of which a person determines the prospects of his professional movement, with ideas about career considered not as a static phenomenon but as a dynamic and changing in time process (Lotova I. P., 2001).

Ideas about career are are to change under the influence of social (political, economic changes in society) and psychological (selfesteem, level of claims, motivation, knowledge, etc.) factors on different stages of training and activity.

The most full in the sphere of the ideas about professional career is the research of career image by I. P. Lotova. Analyzing the image of career way in her study she says that career image is "the integral of actual state of the personality, way of her change and last state". However, such definitions as "the image of the career" and "the image of career way" are synonymous in her work. Although we believe that the career image is a broader and more integrated term, and includes the image of a career way (Moll E. G., 2012).

A number of authors - I. P. Lotova., E. G. Moll, - emphasize the importance of career planning, seeing it as a search for ways of personal improvement to achieve specific goals taking into account individual abilities and limitations (Lotova I. P., 2001).

Conscious planning of professional career, self-management are psychological basis of personality self-realization in the sphere of professional activity. The content and specifics of the profession itself sets a very special trajectory of the career orientation of a person. At the same time professional ideas and ideas about career are rarely the subject of special study.

In their turn professional ideas affect career advancement. Career advancement of the personality can be controlled by society, and by man himself, from the inside, through the system of psychic phenomena that serve as the regulator of the behavior and actions of the personality. Such definitions as "image of the world of the professional", "career ideal", "image of career way", "career image" and others correspond to these phenomena.

To study the career image and the mechanisms of its formation acmeological and program-targeted approach to career planning was applied in psychology.

Program-targeted approach to career planning supposes the formulation of goals system and determination of the concrete activities providing the achievement of these goals by the most effective ways. The function of such planning is the optimization of career and the intensification of personal development. The product of career planning is the image of the future career and means of its creation. The image of the future career performs the function of the regulation of career creation. Its content includes the stages of a career, means, and deadlines for their realization. Based on the position that "external reasons act through internal conditions" we can suppose that "interior condition" of the effective career growth is career planning.

From the point of view of acmeological approach a system forming factor of the image of the future career is the final position, the purpose of personal and professional development. It is determined by the age of the state employee, speed of promotion, the position, the number of steps passed during management way. The final goal defines the spatial - temporal characteristics of the image of the future career way. The higher planned final level of hierarchy of the state service system assumes a greater number of planned steps, a later age of going to the last position - the increase of the planned time interval.

Content of career image can be an idea of the most proper profession. One of the important factors affecting the content and characteristics of the career image is age. It determines the content of the image - goals, factors of satisfaction with the career, and also stability and variability, the degree of elaboration of means of image achievement, reality. For example, E.G. Moll, analyzing managers in her study, says that young leaders (under 35 years) include career in the image the plans covering longer time periods and most of the remaining managerial way than the plans of middle management (36 - 45 years) and senior (46 - 55 years).

The content and characteristics of the professional career image are influenced by the social and psychological and personal characteristics of the subjects: sex-role and 
professional role expectations and identity, type of the personality and correspondence to his social environment, values orientation, peculiarities of motivational-requirement sphere, abilities, intentional characteristics, Iconcept, peculiarities self-assessment, the level of internality, self-confidence and anxiety, character peculiarities, peculiarities of cognitive sphere and self-consciousness, awareness. Also the ideals are affected by individual characteristics of the subjects: genetic factors, age and stage of life, gender, physiological characteristics.

\subsection{The structure of the career image}

After analyzing the researches of domestic and foreign authors we have identified the following structural components of the career image:

The duration of the position number means the amount of planned steps (positions), levels of management hierarchy, refers to the spatial characteristics.

Time or temporal characteristics of the career image are determined by age boundaries of planning.

The sequence as a characteristic of the image of the future is determined by the presence of the image of all levels of the management hierarchy within the space, absence of repetitions or omissions. The empirical indicator of sequence violation is the ratio of the number of missed or repeated levels to the length of planning position number.

Duration as a characteristic of the image of the future management way is expressed by the time of the supposed stay on separate position levels. According to I. P . Lotova this time on average is 2-3 years (Pankratova I. A., Anikina O. V., 2015).

Level characteristics of the planned career are a quality content of position number. Drawing an analogy, they can be compared with modality characteristics of sensory-perceptual images.

Intensity - the amount of movement per time unit, the speed of advancement.

Diversity - supposed changes in the sphere of professional activity, system environment.

Accuracy - conformity of the model of really existing hierarchy to the state service system. An indicator of the accuracy is the presence or absence of errors, of various kinds of distortions. An empirical indicator is the ratio of the number of errors (distortions) to the length of the position number.

Adequacy - compliance of the image characteristics to the probable structure of positions substitution. In this context, important is the question of the quality of the applied probable models of substitution. The development of such models is extremely important for personnel services.

Flexibility - the variability of the image as you pass the managerial way in connection with the qualitative dimension of the environment system or internal conditions. It is variability of the model in the course of a professional career in connection with the qualitative changes of the system environment, the organizational or internal conditions. This feature supposes moving the hierarchy ladder not only vertically, but also horizontally, and the also the flexibility of individual career strategy and tactics (Rogov E. I., 2014).

The nearest zone - the characteristic of the nearest planned development of professional career, the time until the start of the first job promotion and its content at the moment of the study. This relationship reflects the relation of confidence degree of state employee in the accuracy of forecast in normal and extreme (high uncertainty level) conditions. The higher the recognition level of conditions of high uncertainty in forecasting that is not connected with career development, the greater the time interval till the nearest supposed job promotion.

The integrity of the image - the presence of the final goal of career development. It can change individual elements (steps) and the ratio between them, but the overall structure and final goal are unchanged. It is taken into account the possibility of loss of the some position levels or the appearance of new ones at overall stable focus on a certain position level.

Involvement in professional activity. This characteristic is associated with the regulatory function of the image and reflects the degree of influence of professional career plan on personality, i.e. how the plan of professional career is realized in personal and professional development.

The constancy - stability, the preservation of the image under the influence of separate factors, including time. The constancy of the image may be characterized by differences between the time of readiness for the entry into a new position (level of the management system hierarchy) and expected (subjectively probable) time of appointment.

The image of a career is a broader concept than the image of a career way. Unlike the image of a career way, a career image is the most integrated category, because it includes an emotional component, bright specific goal and ways of its achievement and can be used to assess what 
affects a person in building his career and what determines his success in the professional career.

Thus the elements of the career image can be divided into three structural components: structural, informative and emotional-evaluative. As structural units of the career image, we consider the beginning of a career way; career way itself; the end of a career way.

The content of the career image includes as the main units: factors influencing the successful passage of career way and adequacy of the career image.

As emotional and evaluative component of the career image we consider the emotional attitude of the respondent to the beginning of a career, the end of a career and to a career way.

Under the career image we mean the result of mental activity, which is an idea of the personality about own career including career goal, ways of its achievement and having a rich emotional color.

The image of a career is a way of regulation of life and professional activity of the personality through goal setting, motives formation, sense formation, stimulation and mobilization. The image of the career performs the functions of emotional reinforcement and planning of career development. It is the regulator of life plans, professional development and building of the career.

\section{MATERIALS AND METHODS}

An empirical study of the structure of the career image was conducted on the example of state employees. The choice of testees is determined by the fact that because of a number of specific aspects of activities that are socially valued, the bureaucracy is a permanent object of scientific research, at that the requirements imposed on the officials are universal for any country in the world. The testees in our study were state employees at different stages of professional development. The total sample amounted to 635 persons, among them 388 women and girls and 247 boys and men. An empirical study was conducted on the basis of the departments "State and municipal management" (students of the 1-st and 5-th courses) and the "Training of state employees" of South Russian Institute of management of Russian Academy of national economy and state service under the President of the Russian Federation.

1. Group "A" (potential state civil employees) - the stage of early professionalization - students of the first course - 164 persons at the age of 17-19 years.
2. Group "B" (state civil employees before entry on the position) - the stage of education finishing - students of the fifth course - 160 persons at the age of 21-23 years.

3. Group "C" (state employees working in the state service from 2 till 5 years) - the stage of initial professional adaptation - 147 persons at the age of 22-35 years.

4. Group "D" (state employees working in the state service from 10 till 20 years) - the stage of professional skill - 164 persons at the age 35-50 years.

To study the peculiarities of the career image of state employees we carried out an empirical research, the aim of which was to reveal the specific content of the structural, informative and emotional-evaluative components of the career image of state employees at different stages of professional formation.

The choice of research methods was based on the principles of comprehensiveness, objectivity and dynamism of studying the psychological peculiarities of the personality.

For that purpose we have chosen the following methods and techniques for research:

- structural component: the author's technique "Career schedule";

- informative component: a projective method "Drawing of the career", the questionnaire of E. Shane "Anchors of career"; the questionnaire of E. G. Moll "Career goals"; method of E. G. Mogilevkin "Factors of career advancement";

- emotional-evaluative component: a projective method "Drawing of the career".

These methods and techniques allow to study the structure and main components of career image and their content at different stages of professional development of the personality.

\section{RESULTS}

We have carried out the analysis of psychological peculiarities of the career image in the process of professional development of state employees.

\subsection{The analysis of the structural component of the career image in the process of professional develop- ment of state civil employees}

In the process of professional development the idea about the average age of starting a career changes in the direction of reduction. 
If on the first stage of professional development the age is 22.6 years, on the stage of professional skill it is 21 year. In our opinion, it is connected with the fact that in the first case the age of starting a career coincides with the age of graduation from the high educational establishment, which suggests that respondents suppose to begin their career immediately after graduation. In the second case, the age of starting a career coincides with the real age to start a career, that's why most testees indicated it.

We have found that the average age of the career peak indicated by the respondents is increased in the process of professional development of the personality (from 35 years on the first stage to 45 years on the last stage). The reference to such age limit on the first stage is due to the fact that this age is associated with full maturity, and indication of the age limit to 45 years at the last stage suggests that the observation of real careers in the state civil service and private experience have an impact on the shift of the border to a more realistic side.

The average number of planned positions indicated by the respondents also changes depending on what stage of professional development is the personality, which in our opinion is quite natural, since gaining professional experience and having worked for several years in the state service, the testees learn the career way more detailed. Thus, with the increase of the number of planned positions, the number of years spent in each position is reduced, because the total number of positions is increased (Table 1).

Table 1. The analysis of the structural component of the career image in the process of professional development of state civil employees

№

The aver- The av- The av- The average Sub age age to erage age erage amount of group start a ca- of career amount years in the

\begin{tabular}{cccccc} 
& & reer & peak & of stages & position \\
\hline 1 & A & 22,6 & 35,3 & 3,9 & 10,2 \\
\hline 2 & B & 22,4 & 40 & 4,3 & 14,4 \\
\hline 3 & C & 20,6 & 41 & 5,1 & 12,1 \\
\hline 4 & D & 21 & 45 & 6,2 & 7,5 \\
\hline
\end{tabular}

It should be noted that in the process of personal professional development the number of respondents that adequately describe the positions of their career way significantly increase (Table 2). This is due to the fact that in the process of professional development the personality not only develops professional skills, but also learns the details of career growth in the organization.

Table 2. Analysis of conformity of the career image to the reality

\begin{tabular}{|c|c|c|c|c|}
\hline \multirow[t]{2}{*}{ № } & \multirow{2}{*}{$\begin{array}{l}\text { Sub } \\
\text { group }\end{array}$} & \multicolumn{3}{|c|}{$\begin{array}{c}\text { Conformity, in } \% \text { from the } \\
\text { number of the testees in the } \\
\text { sample }\end{array}$} \\
\hline & & Conforms & $\begin{array}{l}\text { Partially } \\
\text { conforms }\end{array}$ & $\begin{array}{l}\text { Doesn't } \\
\text { conform }\end{array}$ \\
\hline 1 & A & 0 & 4 & 96 \\
\hline 2 & B & 24 & 11 & 65 \\
\hline 3 & $\mathrm{C}$ & 40 & 7 & 53 \\
\hline 4 & D & 57 & 13 & 30 \\
\hline
\end{tabular}

If at the first stage, practically none of the respondents could correctly indicate the positions planned for substitution, at the last stage of personal professional development $57 \%$ of the testees indicated the positions correctly. It is obvious that the respondents at the first stage of professional development of the personality poorly represent actual official structure of the government, however, with the gaining of their own experience in the state service the idea about their own career becomes clear and adequate.

The analysis of drawings "Career schedule» showed that the nature of the drawing changes depending on the professional experience received by the testees. The drawing «vertical» dominates in groups $\langle\mathrm{A}\rangle,\langle\mathrm{C}\rangle$, «D». In group «D» a drawing of a career schedule «plateau» dominates, i.e. the fifthyear students believe that when you build a career in the state civil service the growth is possible only till a certain position, after which the «career stagnation» comes. It is connected with the fact that during practical training the respondents have an opinion about such career development. Schedule «vertical» indicates that employees with any professional experience and respondents who have little understanding about the career of state employees believe that it is possible to make a rapid career in this professional sphere. 


\subsection{The analysis of the informative component of the career image in the process of professional development of state civil employees}

We have identified a number of features in the content of the drawings. The images of "man" and "the living world" are depicted most frequently. However, the plot of a man is more common in the drawings of the testees of the subgroup " $A$ " (first year students), and in the other three subgroups the image "the world" dominates, the higher the stage of professional development of personality, the image of the "world" is more common $(\mathrm{p}=0.004)$

Only the drawings of the testees of the subgroup "D" have the plots of "state symbols" and "diploma", these stories are connected with the state service and identified with the end of the career in the minds of officials.

After analyzing the size of drawings we can note higher indicators when evaluating the final stage of career and career way for all respondents. The importance of the end of the career increases in the process of professional development, but not significantly - 1.7 times. This is due to the fact that the closer the end of a career, the more important it becomes for the personality. As has been noted a slightly overestimated relation to the importance of a career way is observed in all subgroups, but it is mostly overestimated in the subgroup " $\mathrm{B}$ ".

It should be noted that there is strongly overestimated evaluation of career starting is observed in the subgroup "B". We explain it by the fact that the testees will soon start their career and this event has a great importance for them, while in the remaining three subgroups a neutral attitude to the career starting dominate, due to the fact that for the subgroups " $A$ " the beginning of a career will not come in the near future and for subgroups "C" and " $D$ " it has already started.

The analysis of possible career goals showed that the most significant for all groups of the testees are the financial goals (Table 3).
Table 3. The peculiarities of career goals in the process of professional development

\begin{tabular}{rlcccc}
\hline № & Career goals & A & B & C & D \\
\hline 1 & Financial goals & 1 & 1 & 1 & 1 \\
\hline & Benefit to others, & & & & \\
2 & Russia & 2 & 2 & 5 & 2 \\
\hline 3 & Self-realization & 8 & 3 & 2 & 3 \\
\hline 4 & Respect & 4 & 8 & 3 & 3 \\
\hline 5 & Success & 4 & 5 & 5 & 3 \\
\hline 6 & Power & 6 & 8 & 5 & 3 \\
\hline
\end{tabular}

Freedom, inde-

pendence, autono-

7 my

$36--$

The welfare of the

\begin{tabular}{rlrrrr}
8 & family & 4 & 8 & - & 5 \\
\hline 9 & Rank & 6 & 9 & 4 & 5 \\
\hline 10 & Stability & - & 4 & 4 & 4 \\
\hline 11 & Professionalism & - & 9 & 5 & 3 \\
\hline & Satisfaction
\end{tabular}

Satisfaction with

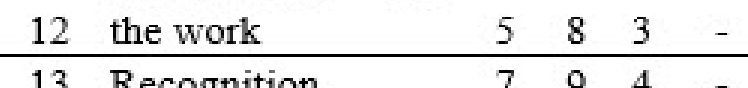

\begin{tabular}{llllll}
13 & Recognition & 7 & 9 & 4 & - \\
\hline 14 & Self-improvement & 8 & 9 & 3 & 5
\end{tabular}

15 Authority $\quad-\quad 8 \quad 4 \quad-$

16 Movement $\quad 5-5-5$

17 Composure $7-5$

18 Relations $\quad 8 \quad 7 \quad-$

19 Self-satisfaction $\quad \begin{array}{lllll}8 & 8 & 3 & -\end{array}$

20 Own business $\quad 8 \quad 8 \quad-\quad-$

$\begin{array}{llllll}21 & \text { Prestige } & 8 & 9 & - & -\end{array}$

$\begin{array}{llllll}22 & \text { Self-respect } & 8 & 9 & - & - \\ 23 & \text { Self-knowledge } & 8 & - & - & 5\end{array}$

24 Experience $\quad-\quad 9 \quad 3 \quad-$

25 Fame $-9-5$

\begin{tabular}{llllll}
\hline 26 & Activity & 8 & - & - & - \\
\hline 27 & Confidence & 8 & - & - & - \\
\hline 28 & Happiness & 8 & - & - & - \\
\hline 29 & Development & - & 9 & - & - \\
\hline
\end{tabular}

The most significant differences were identified between the group " $\mathrm{C}$ " and the other groups $(p=0.003)$ in relation to career goal "benefit to others". While in the three subgroups ("A", "B", "D"), this career goal is second, in the subgroup "C" it goes to fifth place. This is due to the fact that the respondents are just starting their careers and actual for them are goals oriented on the achievement of personal success, because the goal of self-realization is on the second place.

We refer career orientation to the content component of the career image. The analysis 
of the questionnaire "Anchor of the career" allowed to identify a number of characteristics (Table 4).

Table 4. The peculiarities of career orientation in the process of professional development

\begin{tabular}{llllll}
\hline № & $\begin{array}{c}\text { Career orienta- } \\
\text { tions }\end{array}$ & A & B & C & D \\
\hline 1 & $\begin{array}{l}\text { Stability of the } \\
\text { place of the work }\end{array}$ & 1 & 1 & 1 & 2 \\
\hline 2 & Service & 2 & 5 & 5 & 1 \\
\hline 3 & Management & 3 & 3 & 3 & 6 \\
\hline 5 & $\begin{array}{l}\text { Integration of life } \\
\text { styles }\end{array}$ & 4 & 4 & 4 & 3 \\
\hline 6 & Autonomy & 7 & 6 & 6 & 4 \\
\hline 7 & Challenge & 5 & 7 & 7 & 5 \\
\hline 8 & Business & 6 & 2 & 2 & 9 \\
\hline 9 & $\begin{array}{l}\text { Professional } \\
\text { competency }\end{array}$ & 8 & 8 & 8 & 7 \\
\hline 10 & $\begin{array}{l}\text { Stability of resi- } \\
\text { dence }\end{array}$ & 9 & 9 & 9 & 8 \\
\hline
\end{tabular}

Data from Table 4 allow to understand that despite the changes in career orientations of the respondents occurring in the process of professional development, the dominant career orientation for the three subgroups ("A", " $\mathrm{B}$ ", "C") is "stability of the place of work". This orientation is possibly connected with a desire to have guaranteed employment, social benefits and support after retirement and reflects the paternalistic setting inherent for many working people - "organization as a family".

However, the most important career orientation for state employees who are at the stage of professional skills is "service". Taking into account that professional activity of a state employee is directed primarily to the service, the respondents when choosing a future profession of a state employee orient on service to society and the state.

The least significant career orientation for all subgroups is orientation on the "stability of residence".

We also refer the factors influencing the successful career advancement to the informative aspects of the career image (Table 5).
Table 5. The peculiarities of distribution of the factors influencing the successful career advancement in the process of professional development

The factors in-

fluencing the

№ successful ca- A $\quad$ B $\quad$ C $\quad$ D reer advance-

ment

\begin{tabular}{|c|c|c|c|c|c|}
\hline 1 & Intellect & 1 & 1 & 1 & 4 \\
\hline 2 & Money & 7 & 4 & 6 & 6 \\
\hline 3 & Good education & 5 & 6 & 3 & 2 \\
\hline 4 & $\begin{array}{l}\text { Attractive ap- } \\
\text { pearance }\end{array}$ & 8 & 9 & 8 & 0 \\
\hline 5 & Family & 8 & 11 & 9 & 10 \\
\hline 6 & Wittiness & 9 & 10 & 10 & - \\
\hline 7 & Professionalism & 2 & 3 & 2 & 1 \\
\hline 8 & Patience & 8 & 8 & 6 & 8 \\
\hline 9 & Relations & 7 & 4 & 6 & 9 \\
\hline 10 & $\begin{array}{ll}\text { A close rela- } \\
\text { tionship } & \text { with }\end{array}$ & & & & \\
\hline & the boss & 8 & 7 & 10 & - \\
\hline 11 & Experience & 6 & 8 & 7 & 7 \\
\hline 12 & Persistence & 4 & 5 & 5 & 3 \\
\hline 13 & Good luck & 3 & 2 & 4 & 5 \\
\hline
\end{tabular}

According to the respondents who are on the first three stages of professional development of the personality, a factor that has the greatest impact on the career is "intellect", while the state employees who are at the stage of professional skill consider "professionalism" a leading factor, in subgroups " $\mathrm{A}$ " and "C" this factor occupies the second place, and in the subgroup " $\mathrm{B}$ " - the third, due to the fact that the testees attach greater importance to intellectual abilities than to skills and abilities obtained in the course of professional activity.

\subsection{The analysis of the emotional- evaluative component of the career image in the process of professional development of state civil employees}

For the analysis of emotional-evaluative component we used the author's technique "Drawing of the career". The analysis of the emotional-evaluative component of the career image in the process of professional development allowed to reveal a number of peculiarities.

The analysis of the emotional-evaluative component showed that most of the testees 
have dominating neutral attitude towards the start of their career. But the testees who are at the stage of completion of professional education are characterized by a negative attitude to the start of the career $(p=0,0035)$. We believe this is due to the fact that at the stage of career finish the personality starts to miss the past, and also feels competition from the "young" counterparts especially acute. To the peak of the career a positive attitude is dominated in this group.

\section{CONCLUSIONS}

Studying some peculiarities of the structure of the career image at different career stages of professional development, we have conducted extensive theoretical analysis of the problem. We came to the following conclusions:

1. The image of a career is a way of regulation of life and professional activity of the personality through goal setting, motive formation, sense formation, stimulation and mobilization. The image of the career performs the functions of emotional reinforcement and planning of career development. It is the regulator of life plans, professional development and building the career.

2. We found out that the content of the career image components changes depending on what stage of professional development the personality is. The structural component in the process of professional development varies from amorphous and ill-structured at the first stage of professional development to a clear and specific at the last stage of professional development. The career trajectory changes as follows: at the first, third and fourth stages of professional development the most characteristic is the graph of a career "vertical", and at the second stage it is "plateau".

As to the content of career image we can note that the most common for all stages of career development is the dominance of financial goals. The majority of respondents in the first three sub-groups consider a factor that has the greatest impact on a career - "the intellect", at the same time, the testees who are at the stage of professional skill consider "professionalism" a leading factor. In the first three subgroups "stability of the place of the work" has the priority, however for state employees who are at the stage of professional skills the most important career orientation is "service".

Emotional-evaluative component of the career image is maximally differentiated at the second stage of professional development, at all other stages the career image has a common neutral color

The results of the research and its empirical tools can be used by practical psychologists, teachers of high school and personnel employees for revealing the peculiarities of the career image at different stages of professional development; for identifying the possible difficulties which appear when building and passing the career; for applying in the practice of psychological consulting for career development.

The prospects of further work are defined. To continue the research of the career image the following is necessary: the extension of testees sample, selection of the testees from different fields of professional activity; carrying out experimental researches aimed to study the influence of the career image on the professional and career success of the personality.

\section{ACKNOWLEDGEMENTS}

We would like to thank our colleges for valuable feedback and making sure we was true to our research. Thanks are also due to Dr. Alla Belousova and Dr. Evgeniy Rogov, who were coinvestigators in this study.

\section{Conflict of interests}

The authors declare no conflict of interest.

\section{REFERENCES}

Handzic, M., Edwards, J., Moffett, S., Garcia-Perez, A., Kianto, A., \& Bolisani, E. (2016). Knowledge Management Education: Five Ws and One H. Procedia Computer Science, 99, 213-214.

Hanina, I. B. (1990). The question of the professional component of the world image structure. Vestnik MGU. Series 14: Psychology, 3, 42 -50. (in Russian)

Kirt, N. L. (2000). Dynamics of concepts of professional career of educational psychologists in professional self-determination process: $P h D$ Thesis. Moscow. (in Russian).

Klimov, E.A. (1996). Psychology of professional. Moscow: Academy. (in Russian).

Lotova, I. P. (2001). Psycho-acmeological founda-tions of a professional career public servants. Moscow: $M G R S$. (in Russian).

Moll, E. G. (2012). Manager's career management. St. Petersburg: Peter. (in Russian).

Noe, R. A., Noe, A. W., \& Bachhuber, J. A. (1990). An investigation of the correlates of career motivation. Journal of Vocational Behavior, 37(3), 340356.

Pankratova, I. A. \& Anikina, O. V. (2015). Professional performances relationship and empathic abilities 
(IJCRSEE) International Journal of Cognitive Research in Science, Engineering and Education Vol. 4, No.2, 2016.

of students-psychologists. Professional representation, 7, 100-109. (in Russian).

Rogov, E. I. (2014). Professionalism formation psychology. Rostov-on-Don: KIBI MEDIA CENTRE SFU, (in Russian).

Rogova, E .E. \& Pankratova I.A. (2012). Peculiarities of relation of professional orientation and concepts of successful professional activity of students. Science Study, 3(12), 53. (in Russian) http://naukovedenie.ru/sbornik12/12-62.pdf

Rogova, E. E., Pankratova, I. A., Zholudeva, S. V., Sheveleva, A. M., Naumenko, M. V. \& Skrynnik, N. E. (2016). Studying interrelation of professional motivation and professional concepts of specialists with different professional orientation as a basis for career building. International journal of environmental \& science education. 11(17), 10137-10153. http://www.ijese. net/makale/1237

Schein, E. H. (1990). Career Anchors: Discovering Your Real Values Jossey-Bass. San Francisco, California.

Shevelyova, A.M. \& Ivanova, A.I. (2013). Directors' career concepts and motivation. Professional concepts, 1(5), 184-198. (in Russian).

Zagvyazinsky, V. I. (2008). Methodology and methods of psychological and pedagogical research. Moscow, Academia. (in Russian). 